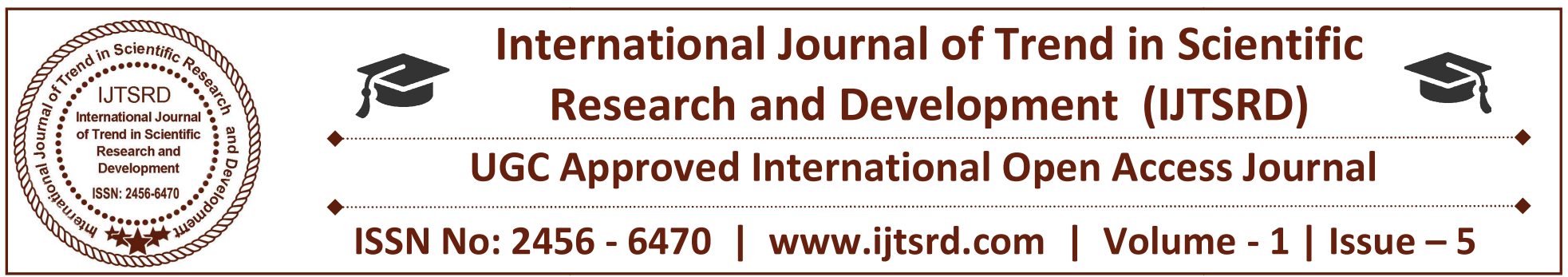

\title{
Consumer Perception of Mobile Advertising Values and their Attitude Towards Mobile Advertising in Anambra State, Nigeria
}

\author{
Okwuchukwu Marcus, Anyasor \\ Chukwuemeka Odumegwu Ojukwu University, Uli, \\ Anambra State, Nigeria
}

\author{
Njideka Nancy, Umeadi. \\ Chukwuemeka Odumegwu Ojukwu University, Uli, \\ Anambra State, Nigeria
}

\section{ABSTRACT}

The study examined if there was relationship between consumer attitude towards mobile advertising and their perception of the informativeness, entertainment, credibility and irritativeness of mobile ads. The questionnaire was used to gather the primary data from of 400 mobile phone (GSM) users in Onitsha metropolis, Anambra State, Nigeria selected through non-probability sampling method. The frequency tables, percentages and Spearman's correlation coefficient were used to analyse the data. The results indicated that entertainment, informativeness, and credibility of mobile advert value leads to $66.9 \%$, $67.6 \%$, and $66.7 \%$ positive effect respectively on the consumer attitude towards mobile advertising; while irritation leads to $15.7 \%$ negative effect on the consumer attitude towards mobile advertising. The study further posit that informativeness $(67.6 \%)$ is the most important factor that impacts on consumers perceptions, followed by entertainment (66.9\%), credibility $(66.7 \%)$, and then irritation $(-15.7 \%)$. The study recommended that marketers need to (i) ensure that messages are sent to consumers at a reasonable time during the day based on consumers' preference. Messages should be sent in suitable amount so as to avoid interruption and disturbance to consumers; (ii) seek ways to increase the level of entertainment pleasurable experience that can be derived from SMS advertisements. To this end, MMS (multimedia message services) substitute is the closest option that can balance out this inherent default SMS entertainment limitation.
Keywords: Attitudes, Mobile ads, Perception, Informativeness, Entertainment, Credibility, Irritation, Anambra State, Nigeria

\section{INTRODUCTION}

In this era, selling strategy has witnessed major development. It has progressed from personally engaging the consumer in a one-to-one persuasive situation to mass marketing even as mass marketing is acknowledged to create only but short term sales. The grim realization that mass marketing cannot yield loyal customers compelled marketers to appreciate the unviability of treating the consumers as a homogeneous group (Spiller \& Baier, 2010). Marketers responded by developing targeted marketing communications that boast the potential of building and maintaining successful and profitable customer relationships. According to Spiller and Baier (2010), targeted marketing is "a database-driven interactive process of directly communicating with targeted customers or prospects using any medium to obtain a measurable response or transaction" which becomes truly successful when associated with direct marketing.

Targeted marketing started with the Internet phenomenon. However, marketers' desire for real time interaction with their customers increased the need for mobile platforms that provide the most dynamic, effective and personal medium for marketing communication (Yaniv, 2008). The 
emergence of the mobile phone and other mobile communication devices bridged this gap. As a means of instant communication, mobile phone no longer served only private purpose as firms also use it to reach out and interact with potential and existing customers (Grant \& Donohoe, 2007; Siau, Sheng \& Nah, 2005). Thus allowing companies to announce their products and services, develop customer relationships through direct personalized and interactive message response from customers (Sultan \& Rohm, 2006).

Marketing adduced relevant reasons as to why the rapid increase in the usage of mobile devices include among others: combination of video and audio contents and contexts (Grant and Donohoe, 2007); flexibility in communication and information sharing enabled by improvements in mobile technology and Internet and computing integration into mobile medium (Siau, Sheng \& Nah, 2005); and the possibility of reaching information anytime and anywhere (Deans, 2005).

Competent scholarly sources have recognized the important role of mobile marketing in marketing information dissemination. It affords the consumers to more easily evaluate marketing information, products/services offerings, and prices prior to making purchase decision which though, according to Urban (2004), has increased the difficulty in predicting his/her behaviour as they expect transparency and real-time interactions with the organisation. As is common with other traditional marketing modes, the success of mobile device platform for communicating, creating sales and building customer relationships is to a very large extent determined by the consumer's attitude. Such attitude is influenced by, amongst others, the perceived utility of the content, the perceived risk associated with data security and, consumer privacy (Bauer, Barnes, Reichardt \& Neumann, 2005).

The mobile phone is seen as a personal device (Barwise and Strong, 2002; Tsang, Ho and Liang, 2004) and as such, marketing messages are expected to meet the individual need and possibly take the form of permission marketing (SMS and/or MMS messages that are requested by the consumer in an opt-in scheme that requires the consumer to indicate their consent to receive commercial messages and information of interest to them) in order to stimulate consumer positive response. Also, as mobile device is one possession many people carry with them points to more reason why a more personalized approach seems to be required in mobile marketing in order to generate a favourable attitude from the consumer (Barwise \& Strong, 2002). Intrusion of marketing messages into this personal device often lead to irritation, especially when the mobile phone is seen as an "extended self" of the consumer as identified by Kolsaker and Drakatos (2009).

Barnes and Scornavacca (2004) and Muk (2007) have earlier posited that academic research in personalized and interactive marketing is still in its infancy despite the huge potentials offered by such messages communicated to the consumers via the mobile phone. This is particularly important in the Nigerian context where little research has been conducted with regard to consumers' perceptions of mobile advertising and also the impact of sending advertisements to consumers via mobile. This is more so when the success of such novel advertising medium relies strongly on its acceptance by the consumers (Bauer, Barnes, Reichardt and Neumann, 2005).

On the ground that majority of researches conducted in this study area have been in foreign countries where the findings, due to cultural differences and differences in the adoption of technology, may not directly apply to Nigerian environment, a partial replication of the study conducted by Tsang, Ho and Ling (2004) in the Nigerian context becomes justifiable. Therefore, the study seeks to determine whether there is a correlation between consumer perceptions of the value of mobile advertisements and consumers' attitude towards mobile advertisements. Specifically, it seeks to determine the relationship between the consumer's perceptions of the entertainment, informativeness, credibility and irritativeness values of mobile advertising and consumers' overall attitude towards mobile advertisements

\section{REVIEW OF RELATED LITERATURE}

Advertising basically provides information about products and services to intending consumers and thus help them to make choices among alternatives based on their need and want problems confronting them. The ultimate purpose of advertising is to make the audience develop favourable attitude toward and to purchase such products and services either immediately or in future. It also reinforces and reminds patrons that they have made the right choice. Various theoretical definitions of advertising are 
unanimous that it is a sponsored, commercially motivated non-personal paid media-borne form of promotion of products, services and ideas.

The relevance of advertising to attitude change and conditioning can be deduced from Morden (1991) and Ayanwale, Alimi and Ayanbimpe (2005) who pointed that it is used to position and establish basic awareness of product/service of a firm in the mind of the potential customer and, build knowledge about it and take eventual purchase decision. Advertisers therefore, use any medium they perceive that can appeal to the prospects. Now that the use of mobile phones has become a lifestyle, advertisers have advanced to using the mobile advertising medium to reach the target audience.

\section{Mobile Advertising}

Few definitions of mobile advertising relevant to this study show that the key contact point of the advertiser with the intended consumers is their mobile phones. The ad message is transmitted through a wireless network directly to and received in the mobile phones of the target audience (Yang, 2007; Altuna \& Konuk, 2009); Plavini \& Durgesh, 2011; Li \& Lee, 2006; Li \& Stoller, 2007; Mobile Marketing Association, 2005; $\mathrm{Xu}, 2007)$. In this way it provides consumers with the convenience of time- and location, and personalized information that promotes products and services and ultimately benefits all stakeholders (Scharl, Dickinger \& Murphy, 2005).

Mobile advertising is characterized by its interactiveness, individualized (Chowdhury, Parvin Weitenberner, \& Becker, 2006) and ubiquity (Muk, 2007). Rapid, easy, cheap and effective interaction is provided between consumers and companies in mobile advertising. In fact, it is the only advertising medium that consumers carry with them almost anywhere they go. The ubiquity of the mobile phone extends the time and space aspect of the traditional mass media advertising (Muk, 2007). Chang and Villegas (2008) argue that mobile phone has tremendous potential for delivering advertisements successfully because of its high penetration rate. Delivery of advertisements to consumers this way cuts down time and space limitations. The rapid spread of mobile advertisements has necessitated some rules and regulations in some countries that it becomes necessary to get the approval of the consumer before sending ad messages (Altuna \& Konuk, 2009).
Typically, the term mobile advertising and SMS or text message advertising are used interchangeably to describe marketing messages in text format sent via mobile phones. This is perhaps because SMS advertising is the most popular form of mobile advertising (Scharl, Dickinger \& Murphy, 2005). However, mobile advertising offers many different options for implementing advertising campaigns. For example, MMS messaging allows the marketer to send multimedia content such as pictures, audio or even animations to selected target groups. Consumers seem to prefer MMS adverts to SMS messaging (Heinonen \& Strandvik, 2007). Expectedly MMS messaging has blossomed with the advent of android phones.

\section{Concept of Consumer Attitude}

Attitude defines the manner an individual thinks feels and/or acts with respect to some aspects of things around him (Anyasor, 2016). In general, researchers seem to agree that attitudes reflect a person's response and feeling toward a given object. For example, Arnould, Price and Zinkhan (2002) states that an attitude is an overall, enduring evaluation of a concept or object, such as a person, a brand or a service. Fishbein (1967) definition points that attitude is a person's learned predisposition that makes him respond in a fairly consistent way towards things, object, idea or opinions. According to Hawkins, Best and Coney (2005), it is a feeling of favourableness or unfavourableness that an individual has towards an object - product/service, brand, price, store and dealer, salesperson, advertisement and promotions - resulting from evaluation of such object. It is a learned predisposition to exhibit and act based on evaluation resulting in a feeling of like or dislike towards an object (Kotler \& Keller, 2009). With regard to consumer behaviour, Cant, Brink and Brijball (2006) emphasized that consumer attitudes may be an inner feeling of favourableness or unfavourableness towards a product/service offering and the 4Ps.

Attitude structure depicts the characteristics of attitude and how they shape consumer perception of market stimuli such as advertising (Aaker, Kumar \& Day, 1998). Attitude is composed of three components or processes - cognitive/knowledge component, affect/feeling component and a conative/behavioural component (Cronje, Du Toit, Marais \& Motlatla, 2004; Hawkins, Best, Coney \& Mookerjee, 2004). Cognitive and affective components are unobservable mind order structures (Shiu, Hair, Bush \& Ortinau (2009) while, 
conative is behavioural. Beliefs, thinking, understanding, evaluating, deciding are cognitive actions (Triandis, 1971; Friman, 2010). In addition, Leon and Kanuk (2000) stated that the knowledge component is reflected in the learning a consumer obtains from his interaction with others as well as his own experiences. In terms of consumer learning, attitude expresses consumer's feeling of like or dislike about a product/service offering and the marketing mix. Affective is expressed in feelings, moods, emotions and remembered sensations (Arnould, Price \& Zinkhan, 2002; Triandis, 1971). It is also reflected in reflected a consumer's evaluation, and the resultant favourableness and unfavourableness considerations. Conation on the other hand refers to the intentions and actual behaviour of the consumer, for example, purchase (action) of a product (Triandis, 1971). It is reflected in the predisposition to act (purchase) based on the evaluation.

Apart from helping a consumer make evaluations about a product/service offering ending up in purchase decisions (to buy/not to buy), attitudes play other functions as well (Strydom, Jooste \& Cant, 2000). Generally, it performs four basic functions according to Cronje, Du Toit, Marais \& Motlatla (2004) and Cant, Brink \& Brijball (2006) namely, utilitarian function, ego defensive function, value expressive function, and knowledge function. The four functions are not mutually exclusive; but rather related to each other and illustrate combination of the functions.

\section{Empirical Review}

Findings of current and past empirical researches (e.g. Blanco, Blasco \& Azorín, 2010; Tsang, Ho, \& Liang, 2004; Javid, Namin, \& Noorai, 2012; Chowdhury, Parvin, Weitenberner \& Becker, 2006; Chia-Ling, Rudolf, Sinkovics \& Parissa, 2012; Waldt, Rebello \& Brown, 2009; Zabadi, Shura \& Elsayed, 2012; Nandagopal, Ha, Balamurugan, Sathish, Sathyanarayanan \& Jublee, 2012; Kamphuis \& Ramnarain, 2012) on consumers' attitudes towards mobile/SMS advertisements are unanimous that informativeness, credibility, and entertainment values are positively associated to consumers' overall attitudes. Chia-Ling, Rudolf, Sinkovics and Parissa (2012) have used infotainment to refer to informativeness, and entertainment, while Nandagopal, Ha, Balamurugan, Sathish, Sathyanarayanan and Jublee (2012) substituted enjoyment for entertainment. Thus, Liu and Jang
(2013) posit that attitude toward mobile advertising is deyermined by the ad's informativeness, entertainment, and credibility.

The findings of Chowdhury, Parvin, Weitenberner and Becker (2006) showed that credibility is the most significant of the factors that affect consumer's attitude toward mobile advertisements. The study also established that a pleasing mobile advertisement with appropriate information will not annoy the consumer.

Kamphuis and Ramnarain (2012) indicated that originality, interactivity and entertainment levels of mobile advertising are more positive to consumer's predispositions compared to traditional forms of advertising. They further showed message content to be an important factor in order for the consumer to perceive the advertising as positive and, the more the consumer likes searching for product information, the more positive the attitude toward mobile advertising will be. They posited that when mobile advertising is used in a proper way, consumers' attitudes can be positive.

On the other hand, studies have found irritation as an impediment to successful mobile advertising. It is negatively correlated with consumers' attitudes towards mobile/SMS advertisements (Waldt, Rebello \& Brown, 2009; Javid, Namin \& Noorai, 2012; Zabadi, Shura \& Elsayed, 2012). Permission based marketing, i.e. sending mobile/SMS ads only to those who have agreed to receive such is solution to irritation and thus ensures success for the ads (Waldt, Rebello \& Brown, 2009).

The extent of impact of mobile ads values as studied by Islam, Kang and Yang (2013) show that informativeness and credibility had significant impacts on attitude towards mobile advertising whereas other factors such as entertainment, irritation, and interactivity were not statistically significant.

\section{THEORETICAL FRAMEWORK}

Theory of Reasoned Action (TRA) developed by Fishbein and Ajzen $(1975,1980)$ is used to explain consumer attitudes toward mobile advertising. The theory was derived from social psychology, particularly from previous research that started out as the theory of attitude, which led to the study of attitude and behaviour. It is considered to be one of the most fundamental and influential theories used broadly to predict and explain human behaviour in 
various domains (Eagly \& Chaiken, 1993; Chen \& Hitt, 2002; Venkatesh, Morris, Davis \& Davis, 2003).

The three major constructs of the TRA are attitude, intention and behaviour. TRA links individual beliefs, attitudes, intentions, and behaviour to describe the psychological process that mediates the observed relations between attitudes and behaviour (Tsang, Ho, and Liang, 2004). Attitude toward advertisements is counted as an important explanatory variable in measuring consumer response to advertising (Mackenzie \& Lutz, 1989). Attitudes in general are mental states used by individuals to structure the way they perceive their environment and guide the way they respond to it (Aaker, Kumar \& Day, 1995). Attitude of an individual towards an object can be seen as his/her internal evaluation of that object on the basis of his/her beliefs (Fishbein and Ajzen, 1975).

As one of the most systematic and extensively applied approach to attitude and behaviour research, TRA has shown its strength in predicting the link between attitude towards the behaviour and behavioural intention (Sheppard, Hartwick, \& Warshaw, 1988). However, this theory has been criticised for its assumption that it is a complete theory and that any other factors will only have indirect influences on behavioural intentions through the constructs of attitude and subjective norms (Eagly \& Chaiken, 1993). Additionally, in TRA: (1) behavioural intention cannot change prior to performance of the behaviour; (2) the theory applies to behaviour that is under the individual's volitional control and does not suit behaviours that may be mandated in some way, or impeded by personal deficiencies and/or external obstacles (Fishbein \& Ajzen, 1975).

TRA is suitable to describing mobile advertisements acceptance behaviour - attitude, intention, and behaviour which are the major constructs of the theory. The present four variables/factor model regarding the acceptance of mobile advertising by consumers has been developed on the basis of this theory. Although there may be various factors that may lead to the acceptance of mobile advertising by consumers, yet the current proposed model focused on only four important variables namely entertainment, informativeness, irritation and credibility.

\section{A model of factors affecting consumer attitudes towards mobile ad}

As attitude towards mobile advertising has been described as a learned predisposition to exhibit and act based on evaluation resulting in a feeling of like or dislike towards and object (Kotler \& Keller, 2009); showing that some factors can determine this predisposition. Several models reflecting the factors that can influence attitude have been studied in the literature. The present study models the variables in the figure below to represent the factors affecting consumer attitude. The figure indicates the various components of the framework with attitude toward advertising via mobile devices as the dependent variable.

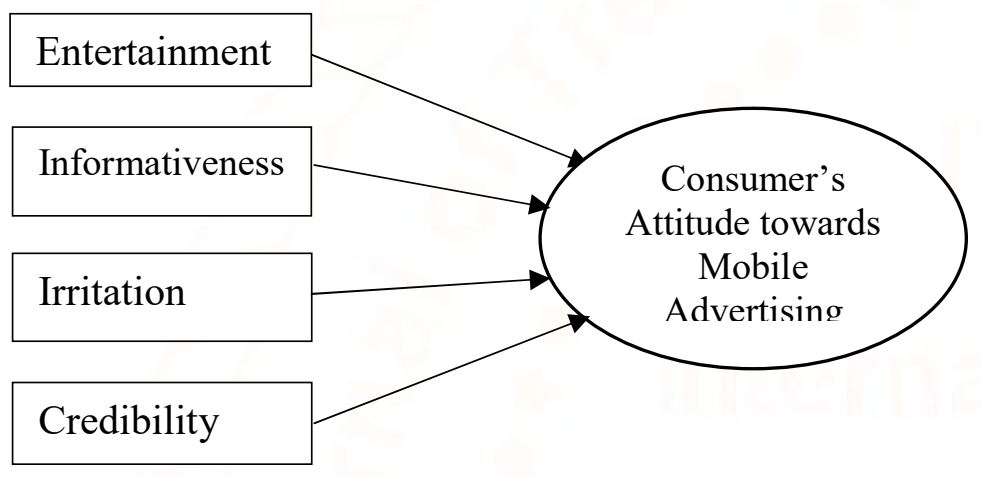

\section{Antecedents of Advertising via Mobile Devices towards Attitude}

Source: Adapted from Chowdhury, Parvin, Weitenberner and Becker (2006)

\section{Entertainment}

Entertainment fulfils “... an audience's needs for escapism, diversion, aesthetic enjoyment, or emotional enjoyment" (Ducoffe, 1996). There are lots of entertainment services provided through mobile marketing such as listening to music, playing games, gambling, watching television, video and sports etc.; mobile phone, therefore, has become a popular media platform for information and entertainment. People's feeling of enjoyment associated with advertisements play dominant role in accounting for their overall favourable attitudes toward them (Shavitt, Lowrey \& Haefner, 1998). Entertainment services can add value for the customer and increase customer loyalty. As most people have natural playfulness, providing games and prizes via text messaging (SMS) yields high participation, so also delivering games and prizes to the target group's mobile phones is a successful way to attract and keep customers (Haghirian \& Dickinger, 2004). Interactive games for example can also be played via text messages. These features can be used to involve customers more deeply and make 
them more familiar with the advertised service or product (Krishnamurthy, 2000). Therefore, we concur with Bauer, Barnes, Reichardt \& Neumann (2005) that an entertaining advertising message is being perceived more positively by the recipient.

Entertainment element in mobile advertising can fulfil consumers' needs for aesthetic enjoyment and emotional release (Ducoffe, 1996). Based on study, Bauer, Barnes, Reichardt and Neumann (2005) found that hedonic pleasure (perceived entertainment value) had a positive effect on attitudes towards advertising. Therefore perceived entertainment value of mobile advertisement will be one of the important factor affecting consumers' attitudes toward advertising.

\section{Informativeness}

Informativeness of advertising is when the ad is capable of informing consumers of available product options (Ducoffe, 1996). The quality of information placed on a company's web site carries direct influence on the customers' perceptions of the company and the company's products. Accordingly, information delivered to them via mobile devices also needs to show qualitative features like accuracy, timeliness, and usefulness for the consumer as they are interested in getting relevant and pertinent messages (Siau \& Shen, 2003; Milne \& Gordon, 1993). Consumers always want quick access to information that they are looking for. In any event, consumers desire the content of the ad messages to be tailored to their interest (Robins, 2003). Information is thus considered a valuable incentive in mobile marketing because recipients react very positively to advertisement that transfers such incentives (Varshney, 2003). Not surprisingly, informativeness of advertising is posited to be strongly related to the advertising value when it is transferred via traditional media vehicles (Ducoffe, 1995).

Wang, Sun, Lei, and Toncar (2009) have argued that the information-seeking factor acts as a positive predictor for the formation of consumers' attitude towards online advertising. Therefore, we conclude that informativeness of an advertising message positively influences consumer attitude toward the advertisement.

The model above has been used in studies (e.g. Tsang, Ho \& Liang, 2004; Brackett \& Carr, 2001) to illustrate that there is a positive correlation between consumers' perceptions of the informativeness of mobile advertisements and consumers' attitudes towards mobile advertisements.

\section{Irritation}

In the context of advertising, irritation arises when the ad is perceived to be annoying, offensive, insulting, or unscrupulous and cunning (Ducoffe, 1996). Shavitt, Lowrey and Haefner (1998) posit that people feel undignified when exposed to such advertisements and so very gravely influence their attitude toward advertising. Mobile advertising may provide an array of information that can confuse, distract and overwhelm the consumer (Stewart, 2004). Consumers may feel confused about them and react negatively. Another point of possible annoyance is unwanted messages, commonly known as spam (Dickinger, 2005). Spam messages intrude into consumers' privacy and stifle consumer acceptance. We therefore conclude that irritation caused by an incomprehensive or unwanted mobile advertising message may reflect negatively on the perceived advertising value of mobile marketing. The relationship between consumers' perceptions of the irritation of an advertisement and consumers' attitudes towards an advertisement is theoretically supported by the attitude model developed by (Brackett \& Carr, 2001).

\section{Credibility}

Ad is seen as credible when it is believable. In the context of advertising industry, MacKenzie and Lutz (1989) identify advertising credibility as consumers' general perception towards the truthfulness, reliability, trustworthiness and believability of an advertisement. This is supported by Brackett and Carr (2001) who states that credibility of advertising is how truthful and believable the consumer perceives it. Credibility of an advertisement is affected by various factors, particularly by the credibility of the company producing the product and the person (source) who brings the message (Goldsmith, Lafferty \& Newell, 2000).

\section{METHODOLOGY}

This study is descriptive survey research. The study site is the metropolitan city of Onitsha in Anambra State, South-Eastern of Nigeria. The city cuts across Onitsha-North and Onitsha-South Local Government Areas of the state. Testing the attitude of consumers towards mobile advertising in Onitsha may make a good representative of Nigerian society. The city 
could rightly be regarded as the commercial nerve centre of the Eastern Nigeria, hence the microcosm of the Nigeria society where people of different income groups, cultural and religious background converge.

The study population comprises of mobile phone users in the metropolitan city, within the ages of 1550years. Marketing literatures that focus on mobile devices (e.g. Cant, Brink \& Brijball, 2005; Macgregor, 2004: Ligerakis, 2004) have identified this age group as the heaviest users of mobile services, as a way of socializing and maintaining realtime relationship. Also, they are more open to new information communication technologies (Lightner, Yenisey, Ozok \& Salvendy, 2002; Pijpers, Bemelmans, Heemstra \& Van Montfort, 2001). Therefore, persons within this age group who own and have access to a mobile phone were eligible to participate in this study.

\section{Sample and Sampling Techniques}

The primary data for this study was sourced from a sample of 400 mobile phone users in the study site. The sample size was derived with a standard formula: $\mathrm{SS}=\mathrm{Z}^{2} \times(\mathrm{p}) \times(1-\mathrm{p}) / \mathrm{C}^{2}$, used for an infinite population or where the population is greater than 50,000 (Freeman, Pisani, and Purves, 1997) or 10,000 (Babalola, 1998). The calculated sample size was 384 respondents, but was increased to 400 for replacement of likely none or missing responses, as well as to increase the adequacy of the sample.

The respondents were selected through convenience on the consideration of their accessibility and availability. Both genders were selected to participate to reflect fair gender balance. In addition to owning a mobile, the participant must be resident in Onitsha to be considered for participation. Structured questionnaire was used for the data collection. A standard Consumer Attitude towards Mobile Advertising questionnaire (CAMAQ) instrument was adapted from Chowdhury, Parvin, Weitenberner, and Becker (2006) and Zabadi, Shura, and Elsayed, (2012). The instrument has two parts: Part I is the demographic characteristics - gender, age, education and occupation of the respondents; Part II, divided into five sections of 13-item questions, addressed the research objectives. The 13 question-items of the questionnaire are structured into Likert-type 4-point scale, from Strongly Disagree $(\mathrm{SD}=1)$ to Strongly Agree $(\mathrm{SA}=4)$. The validity and reliability of the instrument were checked for and ensured through expert opinions and Cronbach alpha test.

The field study took place in the third quarter of 2016. The researcher distributed copies of the questionnaire with the assistance of four trained field assistants who were conversant with Onitsha environment. During administration of the questionnaire, potential respondent was asked if he/she owned or have access to a mobile phone and whether he/she had in the past one month received marketing messages on product/services on their phones. Frequency tables, percentages and Spearman Correlation Coefficient (rho), worked on SPSS version 20, were used in the data analysis.

\section{Data Analysis and Results}

The 400 questionnaires distributed were properly completed and retrieved indicating 100\% return rate. Therefore, the 400 respondents that participated in the study were used in the analyses. Results in Tables 2, 3, 4 and 5 below are non-parametric, Spearman's Rank Order correlation analysis of relationship between consumer perceptions of mobile ads values of entertainment, informativeness, irritation and credibility and consumers' overall attitude towards mobile advertisements. The results answer research question 1, 2, 3, and 4 and, test the corresponding hypotheses. 


\section{Analysis of Demographic Data}

Table 1: Distribution of Respondents' Characteristics

\begin{tabular}{|c|c|c|c|c|}
\hline SN & Variables & & Frequency & $(\%)$ \\
\hline \multirow[t]{2}{*}{1} & Gender & $\begin{array}{l}\text { Male } \\
\text { Female }\end{array}$ & $\begin{array}{l}185 \\
215\end{array}$ & $\begin{array}{l}46.3 \\
53.8\end{array}$ \\
\hline & & Total & 400 & 100 \\
\hline \multirow[t]{2}{*}{2} & Age & $\begin{array}{l}<20 \mathrm{yrs} \\
21-30 \mathrm{yrs} \\
31-40 \mathrm{yrs} \\
41-50 \mathrm{yrs} \\
>50 \mathrm{yrs}\end{array}$ & $\begin{array}{c}56 \\
125 \\
108 \\
62 \\
49\end{array}$ & $\begin{array}{l}14.0 \\
31.3 \\
27.0 \\
15.5 \\
12.3\end{array}$ \\
\hline & & Total & 400 & 100 \\
\hline \multirow[t]{2}{*}{3} & $\begin{array}{l}\text { Educational } \\
\text { background }\end{array}$ & $\begin{array}{l}\text { Primary } \\
\text { High School } \\
\text { Undergraduate } \\
\text { Graduate }\end{array}$ & $\begin{array}{r}60 \\
160 \\
144 \\
36 \\
\end{array}$ & $\begin{array}{r}15.0 \\
40.0 \\
36.0 \\
9.0\end{array}$ \\
\hline & & Total & 136 & 100 \\
\hline \multirow[t]{2}{*}{4} & Occupation & $\begin{array}{l}\text { Student } \\
\text { Company employee } \\
\text { Private Owner } \\
\text { Government Official } \\
\text { Others }\end{array}$ & $\begin{array}{c}52 \\
92 \\
220 \\
24 \\
12 \\
\end{array}$ & $\begin{array}{c}13.0 \\
23.0 \\
55.0 \\
6.0 \\
3.0\end{array}$ \\
\hline & & Total & 136 & 100 \\
\hline
\end{tabular}

The results on the above Table 4.1 above show that there are 185 males representing $46.3 \%$ of the sample and 215 females representing $53.7 \%$ of the sample. This indicated that more females than males participated in the study. The age distribution of the respondents indicated that persons below 20 years are 56 (14\%); between 21 and 30 years are $125(31.3 \%)$; between 31 and 40 are $108(27 \%)$; between 41 and 50 years are $62(15.5 \%)$, while persons above 50 years are $49(12.3 \%)$. The result shows that majority of the participants are persons within the age bracket of 21 and 30 years followed by those between 31 and 40 years of age.

On the educational background of the respondents, result indicates that $60(15 \%)$ participants had primary school education; $160(40 \%)$ had high school education, $144(36 \%)$ are undergraduates while, 36 (9\%) are graduates. From the results, it can be seen that majority of the respondents are mobile phone users with high school education. Further analysis show the result of the distribution of the occupation of the respondents. The results show that the participants are $52(13 \%)$ students, $92(23 \%)$ company employees, $220(55 \%)$ private business owners, 24 (6\%) government officials and 12 (3) others. The result indicate that majority of the respondents are private business owners thus, confirming the status of Onitsha as a commercial city.

In conclusion, the sample of the study is equitably distributed by gender, and all the groups involved in the study are well represented by age, educational; background, and occupation. However, majority of the participants are female, between the age brackets of 21 to 40 years, most high school who are private owners of business centres. These participants are a good representative of Onitsha city where majority of the residents are traders and young population having only basic education who actively involved in private commercial activities.

2. rho Analysis of Relationship between Consumer Perceptions of Entertainment, Informativeness, Irritation, and Credibility Values of mobile Advertisements and Consumers' Attitude towards the Ads. 
Q1: What is the relationship between consumer perception of the value of entertainment of mobile advertisements and their overall attitude towards mobile advertisements?

\section{Ho1: Perceived entertainment of mobile advertising do not have positive effect on attitude toward mobile advertising.}

Table 2: Results of rho: Relationship between consumer perceptions of the value of entertainment and consumers' overall attitude towards mobile advertisements

\begin{tabular}{|l|l|l|l|}
\hline & & & Entertainment \\
\hline $\begin{array}{l}\text { Spearm } \\
\text { an's } \\
\text { rho }\end{array}$ & $\begin{array}{l}\text { Overall } \\
\text { Attitude }\end{array}$ & $\begin{array}{l}\text { Correlation } \\
\text { Coefficient }\end{array}$ & $.669^{* *}$ \\
\hline & & $\begin{array}{l}\text { Sig. } \\
\text { tailed) }\end{array}$ & $(2-$ \\
\hline & & $\mathrm{N}$ & .000 \\
\hline
\end{tabular}

**. Correlation is significant at the 0.01 level (2tailed).

The result for research question one is 0.669 . Based on decision rule, there is a moderate positive relationship between consumer perceptions of the value of entertainment of mobile advertisements and consumers' overall attitude towards mobile advertisements. This means that a unit improvement in the entertainment value of mobile adverts will lead to $66.9 \%$ increase in a positive attitude towards mobile advertising and thus positive attitude towards the product advertised.

The resulting $p$-value $(p=0.000)$ is less than 0.05 , so, we reject the null hypothesis. Thus the study conclude that the perceived entertainment of mobile advertising have direct positive effect on attitude toward mobile advertising and, that mobile advert value of entertainment leads to $67 \%$ positive effect on the consumer attitude towards mobile advertising.

Q2: What is the relationship between consumer perceptions of the value of informativeness of mobile advertisements and their overall attitude towards mobile advertisements?
Ho2: Perceived informativeness of mobile advertising do not have positive effect on attitude toward mobile advertising.

Table 3: Results of rho: Relationship between consumer perceptions of the value of informativeness and consumers' overall attitude towards mobile advertisements

\begin{tabular}{|l|l|l|l|}
\hline & & & Informativeness \\
\hline $\begin{array}{l}\text { Spearm } \\
\text { an's rho }\end{array}$ & $\begin{array}{l}\text { Overall } \\
\text { Attitude }\end{array}$ & $\begin{array}{l}\text { Correlation } \\
\text { Coefficient }\end{array}$ & $.676^{* *}$ \\
\hline & & $\begin{array}{l}\text { Sig. } \\
\text { tailed })\end{array}$ & .000 \\
\hline & & $\mathrm{N}$ & 400 \\
\hline
\end{tabular}

**. Correlation is significant at the 0.01 level (2tailed).

The The result for research question two is 0.676 . Based on decision rule, there is a moderate positive relationship between consumer perceptions of the value of informativeness of mobile advertisements and consumers' overall attitude towards mobile advertisements. This means that a unit improvement in the informativeness of mobile adverts will lead to $67.6 \%$ increase in a positive attitude towards mobile advertising and thus positive attitude towards the product advertised.

The resulting $p$-value $(p=0.000)$ is less than 0.05 ; thus, we reject the null hypothesis and conclude that the perceived informativeness of mobile advertising have direct positive effect on attitude toward mobile advertising and, that mobile advert informativeness leads to $68 \%$ positive effect on the consumer attitude towards mobile advertising.

Q3: What is the relationship between consumer perceptions of the value of irritation of mobile advertisements and their overall attitude towards mobile advertisements?

Ho3: Perceived irritation of mobile advertising do not have negative effect on attitude toward mobile advertising.

Table 4: Results of rho: Relationship between consumer perceptions of the value of irritation and consumers' overall attitude towards mobile advertisements 


\begin{tabular}{|l|l|l|l|}
\hline & & & Irritability \\
\hline $\begin{array}{l}\text { Spearman's } \\
\text { rho }\end{array}$ & $\begin{array}{l}\text { Overall } \\
\text { Attitude }\end{array}$ & $\begin{array}{l}\text { Correlation } \\
\text { Coefficient }\end{array}$ & $-.157^{* * *}$ \\
\hline & & $\begin{array}{l}\text { Sig. } \\
\text { tailed })\end{array}$ & .002 \\
\hline & & $\mathrm{N}$ & 400 \\
\hline
\end{tabular}

**. Correlation is significant at the 0.01 level (2tailed).

The result for research question three is -0.157 . Based on decision rule, there is a weak negative relationship between consumer perceptions of the value of irritation of mobile advertisements and consumers' overall attitude towards mobile advertisements. This means that a unit increase in the extent of irritation from mobile adverts will lead to $15.76 \%$ decrease in a positive attitude towards mobile advertising. This implies that mobile advertising brings about 15.7\% irritation to consumers which negatively impacts on attitude towards mobile advertising.

The resulting $p$-value $(\mathrm{p}=0.002)$ is less than 0.05 ; thus, we reject the null hypothesis and conclude that the perceived irritability of mobile advertising have direct negative effect on attitude toward mobile advertising and, that mobile advert irritation leads to $15.7 \%$ negative on the consumer attitude towards mobile advertising.

Q4: What is the relationship between consumer perceptions of the value of credibility of mobile advertisements and their overall attitude towards mobile advertisements?

Ho4: Perceived credibility of mobile advertising do not have positive effect on attitude toward mobile advertising.

Table 5: Results of rho: Relationship between consumer perceptions of the value of credibility and consumers' overall attitude towards mobile advertisements

\begin{tabular}{|l|l|l|l|}
\hline & & & Credibility \\
\hline $\begin{array}{l}\text { Spearman's } \\
\text { rho }\end{array}$ & $\begin{array}{l}\text { Overall } \\
\text { Attitude }\end{array}$ & $\begin{array}{l}\text { Correlation } \\
\text { Coefficient }\end{array}$ & $.667^{* * *}$ \\
\hline & & $\begin{array}{l}\text { Sig. (2- } \\
\text { tailed) }\end{array}$ & .000 \\
\hline & & $\mathrm{N}$ & 400 \\
\hline
\end{tabular}

**. Correlation is significant at the 0.01 level (2tailed).
The result for research question four is 0.667 . Based on decision rule, there is a moderate positive relationship between consumer perceptions of the value of credibility of mobile advertisements and consumers' overall attitude towards mobile advertisements. This means that a unit improvement in the credibility of mobile adverts will lead to $66.7 \%$ increase in a positive attitude towards mobile advertising and thus positive attitude towards the product advertised.

The resulting $p$-value $(p=0.000)$ is less than 0.05 ; thus, we reject the null hypothesis and conclude that the perceived credibility of mobile advertising have direct positive effect on attitude toward mobile advertising and, that mobile advert credibility leads to $67 \%$ positive effect on the consumer attitude towards mobile advertising.

\section{Findings and Discussions}

The result of the study has shown that entertainment value of mobile advert: (66.9\%), informativeness $(67.6 \%)$ and credibility $(66.7 \%)$ have positive effect on the consumer attitude towards mobile advertising. However, mobile advert irritation (-15.7\%) has negative effect on the consumer attitude towards mobile advertising.

This findings is in line with findings from previous researches such as Tsang, Ho, and Liang (2004), Chowdhury, Parvin, Weitenberner and Becker (2006), Waldt, Rebello and Brown (2009), Blanco, Blasco and Azorín (2010), Javid, Namin, Noorai (2012), Chia-Ling, Rudolf, Sinkovics and Parissa (2012), Zabadi, Shura and Elsayed (2012), Nandagopal, Ha, Balamurugan, Sathish, Sathyanarayanan and Jublee (2012), Liu and Jang (2013) Ene and Özkaya (2015). These studies generally agree that entertainment, informativeness, and credibility are positively correlated to the overall attitude, whereas irritation is negatively correlated to the overall attitude.

However, the area of disagreement is in the factor of most significance (importance) in designing mobile advertising messages. Though the present study posited that informativeness $(67.6 \%)$ is the most important factor that impacts on consumer perceptions, followed by entertainment (66.9\%), credibility $(66.7 \%)$, and then irritability $(-15.7 \%)$, previous studies postulated other factors. For instance, Tsang, Ho, and Liang (2004) found that entertainment 
was the most significant of the factors affecting respondents' attitudes, followed by credibility and irritation. Chowdhury, Parvin, Weitenberner and Becker (2006) posited that credibility is the most significant of the factors; while Javid, Namin, Noorai (2012) found entertainment to have the most impact on the consumers.

The implication of these findings is that factor of importance varies from country to country. Thus, in Nigeria, informativeness is the most significant factor in mobile advertising. This suggests that Nigerian consumers are more interested in the information content of advertising message they receive. The quality of information content can be represented by the ability of the advert to convey the price and physical as well as the expected invisible qualities that appeal to the consumer. Also, the extent of bonus and other value-added should be given. This presupposes that marketers should pay more attention in designing the information to be communicated to consumers when mobile devices are used as medium for advertising.

\section{Conclusion and Recommendations}

The study has shown that mobile advertising can brings about positive attitude when its entertainment, informativeness and credibility values are improved. This implies that marketers using mobile devices for means of advertising should improve the quality of information delivered and ensure that it assists consumers to make sound decisions. This will reduce post-purchase dissonance and hence increase the level of credibility accorded such adverts. As well, mobile advert that is entertaining will be able to hold the interest of consumers and could enhance consumer loyalty. However, irritation is very disturbing and as such has negative effect on consumers' attitude towards mobile adverts. Thus, a mobile advert that produces irritation is capable of yielding counterproductive results for marketers.

Against this background therefore, Nigerian marketers need to understand the target audience for mobile advertising campaign and send messages that the language and content tally with the target audience's expectations.

Based on the findings of this study, the following recommendations are made. i. The relationship between trust of marketing messages and consumer attitudes, suggests that marketers need to ensure that messages are sent to consumers at a reasonable time during the day based on consumers' preference. Messages should be sent in suitable amount so as to avoid interruption and disturbance to consumers.

ii. Information content of the ads should be apt and, reasonably maintained

iii. With regard to the fairly positive perceptions of the entertainment value, marketers need to look at ways of increasing the entertainment as well as the level of pleasurable experience that can be derived from mobile ads. MMS (multimedia message services) substitute is the closest option that can balance out inherent default entertainment limitation SMS version.

\section{REFERENCES}

1) Aaker, D. A., Kumar, U. and Day, G.S. (1995). Marketing research 5/e. New York: John Wiley.

2) Ajzen, I. \& Fishbein, M. (1980). Understanding Attitudes and Predicting Social Behaviour. New Jersey, Englewood Cliffs: Prentice-Hall.

3) Altuna, O. K. \& Konuk, F. A. (2009).Understanding Consumer Attitudes toward Mobile Advertising and Its Impact on Consumers' Behavioural Intentions: A Cross-Market Comparison of United States and Turkish Consumers. International Journal of Mobile Marketing, 49(2), 43-51.

4) Anyasor, O. M. (2016). Effect of SMS Advertising on Attitudes of Nigeria GSM Phone Users. African Journal of Education, science and Technology, 3(1),

215-2224 http://www.academicresearchguide.com/supportfiles/ajestvol.3no.1jan2016.pdf

5) Arnould, E. J., Price, L. \& Zinkhan, G. (2002). Consumers. New York: McGraw Hill Higher Education

6) Ayanwale, A., Alimi, T., \& Ayanbimipe, M. (2005). The Influence of Advertising on Consumer Brand Preference. Journal of Social Sciences, 10(1), 9-16. 
7) Babalola, S. O. (1998). Research Methods in the Social Sciences. In Babalola, S.O., Ed. Fundamentals of Sociology. Lagos: sociology Department, Lagos State University.

8) Barnes, S. J. \& Scornavacca, E. (2004). Mobile marketing: The Role of Permission and Acceptance. International Journal of Mobile Communication, 2, 26-35.

9) Barwise, P., \& Strong, C. (2002). PermissionBased Mobile Advertising. Journal of Interactive Marketing. 16(1), 45-53.

10) Bauer, H. H., Barnes, S. J., Reichardt, T., and Neumann, M. M. (2005).Driving consumer acceptance of mobile marketing: A theoretical framework and empirical study. Journal of electronic commerce research, 6(3), 181-192.

11) Blanco, C. F., Blasco, M.G. \& Azorin, I. I. (2010). Entertainment and Informativeness as Precursory Factors of Successful Mobile Advertising Messages. Communications of the IBIMA, 130147.

12) Brackett, L. K. \& Carr, B. N. Jr. (2001). Cyberspace Advertising vs. Other Media: Consumer vs. iVIature Student Attitudes. Journal of advertising research, 2, 23-32.

13) Cant, M. C., Brink, A. \& Brijball, S. (2006). Consumer Behaviour. Cape Town: Juta.

14) Chang, H. J. \& Villegas, J. (2008). Mobile Phone User's Behaviour: The Motivation Factors of the Mobile Phone User. International Journal of Mobile Marketing 3(2), 4-14.

15) Chen, P.Y. \& Hitt, L.M. (2002). Measuring Switching Costs and the Determinants of Customer Retention in Internet-enabled Businesses: A study of the Online Brokerage Industry. Information Systems Research 13(3), 255-274.

16) Chia-Ling, E. L., Rudolf, R. Sinkovics, N. P \& Parissa H. (2012).Determinants of Consumer Perceptions toward Mobile Advertising - A Comparison between Japan and Austria. Journal of Interactive Marketing, 26, 21-32.
17) Chowdhury, H. K., Parvin, N., Weitenberner, C. \& Becker, M. (2006), Consumer Attitude toward Mobile Advertising in An Emerging Market: An Empirical Study. International Journal of Mobile Marketing, 1(2), 33-42.

18) Cronbach L. J. (1951). Coefficient alpha and the Internal Structure of Tests. Psychometrika, 16(3), 297-334.

19) Cronje, G. J., Du Toit, G. S., Marais, A. \& Motlatla, M. D. C. (2004).Introduction to Business Management. Cape Town: Oxford University Press.

20) Deans, P. D. (2005). E-commerce and $M$ Commerce Technologies. IRM Press (an imprint of Ideal Group Inc.).

21) Dickinger, A. S. (2005). Diffusion and success factors of mobile Marketing. Electronic Commerce Research and Applications, 4 (2), 159$173 . \quad \mathrm{http}: / / \mathrm{dx}$. doi.org/10.1016/j.elerap. 2004.10.006.

22) Ducoffe, R. H. (1995). How Consumers Assess the Value of Advertising. Journal of Current Issue in Research and Advertising, 17(1), 1-18.

23) Ducoffe. R. H. (1996). Advertising Value and Advertising on the Web. Journal of Advertising Research, 36 (5), 21-35.

24) Eagly, A. \& Chaiken, S. (1993). The Psychology of Attitudes. Orlando. Florida: Harcourt Brace Jovanovich College Publishers.

25) Ene, S. \& Özkaya, B. (2015), The Role of Mobile Advertising on Consumers' Purchase Decisions: A Research on Consumer Attitudes towards Mobile Advertising. International Journal of Humanities and Social Science, 5(1), 235-248. Retrieved from http://www.ijhssnet.com/journals/Vol_5_No_1_Ja nuary_2015/26.pdf.

26) Fishbein, M. (1967). Readings in Attitude Theory and Measurement, Wiley, New York.

27) Fishbein, M.A. \& Ajzen, I. (1975). Belief, Attitude, Intention and Behaviour: An Introduction to Theory and Research. AddisonWesley. 
28) Freeman, D., Pisani, R \& Purves, R. (1997). Statistics, 3/e. Norton \& Company, Incorporated.

29) Goldsmith, R. E., Lafferty, B. A., \& Newell, S. J. (2000).The Impact of Corporate Credibility and Celebrity Credibility on Consumer Reaction to Advertisements and Brands. Journal of Advertising, 29(3), 43-54.

30) Grant, I. \& O'Donohoe, S. (2007). Why Young Consumers are not open to Mobile Marketing Communication. International Journal of Advertising, 26 (2), 223-246.

31) Haghirian P, \& Dickinger A. (2004). Identifying Success Factors of Mobile Marketing. Proceedings of the Asia-Pacific ACR (Association of Consumer Research) Conference. Korea, Seoul.

32) Hawkins, D. I., Best, R. J. and Coney, K.A (2005), Consumer Behaviour, Building Marketing Strategy. New York: McGraw-Hill.

33) Hawkins, D .I., Best, R. J., Coney, K. A. \& Mookerjee, A. (2004).Consumer Behaviour: Building Marketing Strategy, 9/e. NewYork: The McGraw-Hills Companies.

34) Heinonen, K. \& Strandvik, T. (2007). Consumer responsiveness to mobile marketing. International Journal of Mobile Communications, 5(6), 603617.

35) Islam, M., Kang, M. \& Yang, S. (2013). A Research to Identify the Relationship between Consumers' Attitude and Mobile Advertising. Retrieved October 12, 2015 from http://www.pacis-net.org/file/2013/PACIS2013038.pdf.

36) Javid, M. H., Namin, A. T. \& Noorai M. (2012).Prioritization of Factors Affecting Consumers' Attitudes toward Mobile Advertising. Journal of Basic and Applied Scientific Research, 2(9), $98-109$.

37) Kamphuis, K. E. \& Ramnarain, M. C. (2012).Consumer Attitudes toward Mobile Advertising - A Study of the Dutch Youth. Master's Thesis in Business Administration, Jönköping International Business School, Jönköping University. Retrieve from http://hj.diva-

portal.org/smash/get/diva2:531936/FULLTEXT01 .pdf.

38) Katterbach, W. (2002). Die SMS - VerKaufer. Impulse, $1^{\text {st }}$ February, 67.

39) Keskinen, T. (2001). Mobile Marketing Handbook. Helsinki: Advertisers.

40) Kolsaker, A. \& Drakatos, N. (2009). Mobile advertising: the influence of emotional attachment to mobile devices on consumer receptiveness. Journal of Marketing Communications, 15(4), 267-280.

41) Kotler, P. \& Keller, K. L. (2009). Marketing Management, 3/e. Upper Saddle River, New Jersey: Prentice Hal.

42) Krishnamurthy, S. (2000). Permission Marketing: Turning Strangers into Friends, and Friends into Customers. Journal of Marketing Research, 77(4), 171-173.

43) Li, H. \& Lee, K. (2006). Mobile phones and mobile advertising: An Asian perspective. International Journal of Internet Marketing and Advertising, 3(2), 177-192.

44) Li, H., \& Stoller, B. (2007). Parameters of Mobile Advertising: A Field Experiment. International Journal of Mobile Marketing, 2 (1), 4-11.

45) Ligerakis, M. (2004) Move over Gen $Y$, here comes Generation $W$. (online). Retrieved October, 12, 2015 from http://www.bandt.com.au/news/fa/0c0180fa.asp.

46) Lightner, N. J., Yenisey, M. M., Ozok, A. A., \& Salvendy, G. (2002). Shopping Behaviour and Preferences in E-commerce of Turkish and American University Students: Implications from Cross-cultural Design. Behaviour \& Information Technology, 21 (6), 373-385.

47) Liu, W. \& Jang, H. (2013). Factors Affecting Consumer's Perceived Advertising Value and Attitude toward Mobile Advertising: Focus on Company-factors and Consumer-factors. Asian Journal of Business and Management Sciences, 3(2), 44-55. Retrieved from 
International Journal of Trend in Scientific Research and Development (IJTSRD) ISSN: 2456-6470

http://www.ajbms.org/articlepdf/4ajbms20130302 2768.pdf.

48) Macgregor, K. (2004). South Africa's 'Born Frees' have grown up in a free and fair Society that was previously heavily Suppressed and divided by Race. (Online). Retrieved October 12, 2015

from http://allafrica.com/stories/200412030183.html.

49) MacKenzie, S. B. \& Lutz, R. J. (1989). An Empirical Examination of the Structural Antecedents of Attitude toward the Ad in an Advertising Pretesting Context. Journal of Marketing, 53(2), 48-65.

50) Milne, G. R. \& Gordon, E. M. (1993). Direct mail privacy-efficiency trade-offs within an implied social contract framework. Journal of Public Policy and Marketing, 12(2), 26-38.

51) Mobile Marketing Association Global. (2005). Wireless Definitions: MMA Privacy and Spam Definitions. [Online] Retrieved October 16, 2015 from http://mmaglobal.com/modules/ content/indexphp?id $=6$.

52) Morden, A. R. (1991). Elements of Marketing. London: D.P. Publication Ltd.

53) Muk, A. (2007) Consumers' Intentions to Opt in to SMS Advertising. International Journal of Advertising, 26(2), 177-198.

54) Nandagopal, R., Ha, H., Balamurugan, R. N., Sathish, M., Sathyanarayanan, R. S. \& Jublee, D. (2012). Consumer Attitude towards Mobile Advertising and Its Impact on Consumers' Behavioural Intention - A Case Study in Coimbatore City, India. Retrieved from http://www.gcasa.com/conferences/singapore12/papers/Ha1.pdf.

55) Pijpers, G. G. M., Bemelmans, T. M. A., Heemstra, F. J., \& Van Montfort, K.A.G.M. (2001).Senior Executives' Use of Information Technology. Information and Software Technology, 43, 959-971.

56) Plavini, P. \& Durgesh, P. (2011). Attitude towards Mobile Advertising: A Study of Indian
Consumers. Paper presented at the International Conference on Management, Economics and Social Sciences (ICMESS'2011), Bangkok, Dec.

57) Robins, F. (2003). The Marketing of 3G.Journal of Marketing Intelligence Planning. 21(6), 370378.

58) Scharl, A., Dickinger, A. \& Murphy, J. (2005).Diffusion and Success Factors of Mobile Marketing. Electronic Commerce. Research Application, 4(2), 159-173

59) Shavitt, S., Lowrey, P. \& Haefner, J. (1998). Public Attitudes Toward Advertising: More Favourable Than You Might Think. J. Adverting Research, 38(4), 7-22.

60) Sheppard, B. H., Hartwick, J., \& Warshaw, P. R. (1988). The Theory of Reasoned Action: A MetaAnalysis of Past Research with Recommendations for Modifications and Future Research. Journal of Consumer Research, 15(3), 325-343.

61) Shiu, E., Hair, J., Bush, R., \& Ortinau, D. (2009). Marketing Research. Berkshire: McGrawHill Higher Education.

62) Siau, K. \& Shen, Z. (2003). Building Customer Trust in Mobile Commerce. Communications of the ACM, 46(4), 91-94.

63) Siau, K., Sheng, H. \& Nah F. F. (2005). Strategic Implications of Mobile Technology: A case Study using Value-Focused Thinking. Journal of Strategic Information Systems, 14, 269-290.

64) Spiller, L.D. \& Baier, M., (2010). Contemporary Direct \& Interactive Marketing, 2/e. New Jersey: Pearson.

65) Stewart, D. W. (2004). The New face of Interactive Advertising. (Cover story). Marketing Research, 16(1), 10-15.

66) Strydom, J. W., Jooste, C. J. \& Cant, M. C. (2000) Marketing Management, 4/e. Cape Town: Juta \& Co.

67) Sultan, F. \& Rohm, A. (2006). Brand in the Hand: An Exploratory Study of Mobile Marketing Communications. Institute for Global Innovation 
Management, Northeastern University. Retrieved September $\quad 11$, 2015 from: http://www.wsj.com/documents/WSJBrand intheHand.pdf.

68) Triandis, H. C. (1971). Attitude and Attitude Change. NewYork: John Wiley \& Sons.

69) Tsang, M. M., Ho, S. \& Liang, T. (2004). Consumer Attitudes toward Mobile Advertising: An Empirical Study. International Journal of Electronic Commerce, 8 (3), 65-78. Retrieved from http://www.ecrc.nsysu.edu.tw/liang/paper/17Mobile\%20advertising\%20(IJEC\%2020 04).pdf

70) Urban, G. (2004). The Emerging Era of Customer Advocacy. MIT Sloan Management Review, Winter, 77-82.

71) Varshney, U. (2003). Location Management for Mobile Commerce Applications in Wireless Internet Environment. ACM Transact. Internet Technology, 3(3), 236-255.

72) Venkatesh, V., Morris, M. G., Davis, G. B. \& Davis, F. D. (2003). User Acceptance of Information Technology: Toward a unified view.MIS Quarterly,27(3), 425-478.

73) Waldt, V. Rebello, T. \& Brown, W. (2009). Attitudes of Young Consumers towards SMS Advertising. African Journal of Business Management, 3, 444-452. Retrieved from http://www.academicjournals.org/article/article13 80552222_Waldt\%20et\%20al..pdf.
74) Wang, Y., Sun, S., Lei, W., \& Toncar, M. (2009).Examining beliefs and attitudes toward online advertising among Chinese consumer. Journal of International Direct Marketing, 3(1), 52-66.

75) Xu D. J. (2007). The Influence of Personalization in Affecting Consumer Attitudes toward Mobile Advertising in China. Journal of Computer Information Systems.

76) Yaniv, G. (2008). Sold on Mobile Marketing: Effective Wireless Carrier Mobile Advertising and how to make it Even More So. International Journal of Mobile Marketing, 3, 86-91.

77) Yang, K. C.C. (2007). Exploring Factors Affecting Consumer Intention to Use Mobile Advertising in Taiwan. Journal of International Consumer Marketing, 20(1), 33-49.

78) Zabadi, A. M. A., Shura, M. and Elsayed, E. A. (2012). Consumer Attitudes toward SMS Advertising among Jordanian Users. International Journal of Marketing Studies, 4(1), 77-94. Retrieved from http://www.ccsenet.org/journal/index.php/ijms/arti cle/download/ 14770/10162. 